\title{
Megváltoztatni vagy elfogadni? Konverziós és affirmatív terápiák összehasonlító elemzése
}

\author{
Román Boglárka \\ ELTE Pedagógiai és Pszichológiai Kar, Szexuálpszichológiai szakképzés
}

\begin{abstract}
A homoszexualitásról történő véleményalkotás megosztja a társadalom különböző rétegeit és a kutatókat. A megosztó hozzáállás és véleményalkotás szükebb környezetben, családi, baráti közegben egyaránt jelentkezhet. A terápiás munka során akár egyéni, akár szülői oldalról gyakran hangoznak el ilyen és ehhez hasonló tartalmú kérdések: "Miért épp velem történik?” "Hogyan tudnának mások elfogadni?” „Miért vagyok más, mint a többiek?” "Mitől lesz valaki homoszexuális?” "Mi rosszat tettem, hogy ez pont az én gyerekemmel történik?” "Hogyan tudnám Őt így elfogadni?” A sok ellentmondás, a téma tabuvá tétele felerősíti az okok, magyarázatok, válaszok keresésének hajlamát.

Tanulmányomban a lehetséges sokszínü okok feltárására vonatkozó kutatások bemutatása, összefoglalása mellett, a homoszexuálisokkal folytatott különböző terápiás módszerek - konverziós, reparatív (helyreállító) módszer, valamint affirmatív, elfogadáson alapuló módszer - bemutatásán és összehasonlításán keresztül igyekszem az ellentmondások feloldására, az alapvető fogalmak tisztázására helyezni a hangsúlyt. A megértést és elfogadást a tudatosság és tisztánlátás segítheti. Tanulmányomban a „Milyen eszközrendszer segíthet a megértésben?” "Miért lehet fontosabb a megértés és az elfogadás a megváltoztatásnál?” "Mi segítheti a szülöt a gyermekhez való viszonyulásban?” "Ha a szülő a terápiás folyamat eszközét választja, mi segithet a segítő szakmában dolgozóknak, ha esetleg családi, környezetből fakadó elutasitással, kirekesztéssel találkoznak?" kérdésekre keresem a választ.
\end{abstract}

Kulcsszavak: homoszexualitás, terápiás módszerek, helyreállitó módszer, affirmatív módszer, elfogadás

\section{Bevezetés}

A homoszexualitás megítélése, a homoszexualitásról történő véleményalkotás éppúgy megosztja a szakembereket, mint a társadalom különböző rétegeit. Ma már tudományosan általánosan vallott nézetnek tekinthető, hogy a homoszexualitás nem betegség, azonban a társadalmi vélekedések eltérőek és ellentmondásosak.

Magyarországon a heteronormatív, azaz a heteroszexualitást normaként valló társadalmi felfogások következtében az elutasítás, kirekesztés különböző formái általánosak. A homofóbia elfogadásából fakadóan a coming out (előbújás) folyamata nehezített, a homoszexuálisok többségére a rejtőzködés jellemző. Hazánkat tekintve, önbevallás alapján a melegek aránya 5\% felettire tehető. Egy Magyarországon 2010-ben klasszikus közösségi mintán - LMBT-civilszervezetek, LMBT-embereket megcélzó internetes oldalak, LMBT-médiatermékek, szórakozóhelyek, rendezvények segítségével és bevonásával - végzett kutatás során a válaszadók 34\%-a számolt be arról, hogy szexuális irányultsága, 30\%-a arról, hogy nemi identitása kifejezése miatt korábban már érte hátrányos megkülönböztetés (Dombos, 2011). Ezen eredményeken felül ráadásul minden negyedik válaszadó megtapasztalta, hogy szexuális irányultsága, vagy nemi identitása miatt családja, vagy barátai részéröl kirekesztés éri. Családon belül a szexről, a szexuális érdeklődésről történő nyílt kommunikáció sok esetben nem jellemző, a fiatalok gyakran maradnak egyedül kérdéseikkel, a szülők gyakran kezelik tabutémaként gyermekeik nemi életét. Családon belül a heteroszexuálistól eltérő szexuális orientációt jóval többen 
Megváltoztatni vagy elfogadni? Konverziós és affirmatív terápiák összehasonlító elemzése

vállalják fel az édesanyák (43\%), mint az édesapák előtt (31\%). A homoszexualitás felvállalása következtében a családoknál gyakori az elhidegülés, a kapcsolatok megszakadása, a partner kirekesztése, a hárítás folyamata is (Dombos, 2011). A szülők gyakran éreznek bủntudatot, sok esetben úgy vélik, gyermekük nevelése kapcsán rontottak el valamit.

Az ellentmondások kapcsolódnak annak a kérdésnek megválaszolásához is, vajon milyen okot adhatunk magyarázatként a homoszexualitás kialakulására. Melyik tudományterület magyarázata áll legközelebb az igazsághoz és a teljes megértéshez? Az orvostudomány? A biológia? A pszichológia? Mi áll a háttérben? Genetika? Evolúció? Környezeti hatások? Szocializáció? Kultúra? Nevelés?

A genetikai vizsgálatok alapján a melegek teljes génállományát feltérképezve egy bizonyos gén náluk jelentősen gyakoribban jelenik meg, mint a nem meleg népességnél. Mindemellett fontos szempont, hogy a genetikai vizsgálatok önmagukban nem nyújtanak teljes körü magyarázatot. Az összefüggések, az ok-okozat számos más tényező együttes fennállásával lehetne teljes körüen vizsgálható (Whitehead, 1999).

Az orvostudományi-biológiai elméletek szerint a homoszexuális hajlam kialakulásában a legfőbb szerepet a magzatot érő hormonhatások, valamint egyéb immunológiai tényezők töltik be, de befolyásolhatja mindezt az idegrendszer fejlődése is (Hill, 2013). Egypetéjü, kétpetéjü ikrek összehasonlító vizsgálata alapján, ha egy ikerpár egyik tagja homoszexuális, akkor egypetéjű ikreknél az ikertestvérek több mint fele, míg kétpetéjüeknél kb. 20-25\%-a lesz szintén meleg. Családfakutatások esetében a melegek családjában, rokonságában gyakrabban fordulnak elő melegek, mint az átlag népességben. Egy másik vizsgálat szerint a későbbi terhességekből valamivel gyakrabban születik homoszexuális fiú, mint a korábbiakból, vagyis minden terhességgel kismértékben nő a homoszexualitás valószínüsége (Fischer, 2010). Homoszexuálisok és heteroszexuálisok agyi eltéréseit vizsgálva a kutatók azt tapasztalták, hogy a szexuális orientációnak van agyi lenyomata. Az agyra azonban nem az öröklötten merev, hanem a használat függvényében változó rugalmas huzalozottság jellemző. Mindemellett nem bizonyítható egyértelműen, hogy a kapott eredmények a szexuális orientációval volnának egyértelmű összefüggésben (Kinnunen, 2004). A biológiai hátteret vizsgálva, főemlősökön végzett etológiai kutatások szerint az azonos nemü egyedek közötti szexuális vonzalom evolúciós előnyt jelenthetett, hiszen ezáltal csökkent az egymás közötti agresszió, illetve a nem szaporodó egyedek „önfeláldozó” viselkedésének köszönhetően az utódok felnevelése könnyebbé vált (Takács, 2011).

Pszichoanalitikus állásfoglalás szerint a homoszexualitás hátterében a gátlás áll. A másik nemtöl való irracionális félelmek erősek, a férfi homoszexuálisok anyjukkal való kapcsolata igen mély, sok esetben apa nélkül nőnek fel. Az anyában ezeknél az eseteknél megfigyelhető az elutasítás a férfi nem és a szexualitás iránt, valamint a gyerek szexuális érdeklődésével kapcsolatos elítélő attitűd (Bieber, 1962).

A környezetet érintő vizsgálatok alapján elmondható, hogy a hajlam, az alkat az, ami már korán megmutatkozik. Számos vizsgálat bizonyítja, hogy a melegek gyerekkorukban gyakrabban mutatnak a másik nemre jellemző viselkedési jellemzőket, mint a heteroszexuálisok, valamint azt, hogy a melegek már átlagosan három évvel az első szexuális tapasztalatuk előtt tudják magukról, hogy homoszexuálisak (Fischer, 2010).

Más kutatások szerint az urbanizáció és a magas iskolázottság korrelálnak a homoszexualitással, valamint a homoszexuális viselkedéssel (Michael, 1994).

Több vizsgálat foglalkozik azzal, hogy a társadalom hogyan vélekedik a homoszexualitásról, milyen okokat vél a homoszexualitás hátterének tulajdonítani. Egy 2010-ben végzett 1000 fős országosan reprezentatív lakossági magyarországi mintán 
végzett kutatás során a válaszadók leginkább azzal értettek egyet, hogy a homoszexualitás az ember magánügye, ezt követően viszont legtöbben devianciaként, betegségként definiálták a homoszexualitást (Takács, 2011). Egy másik, magyar középiskolai diákok körében végzett vizsgálat alapján a fiúk a homoszexualitást veleszületett, vagy kisgyermekkorban kialakuló rendellenességnek tudják be, melyet többnyire férfiak közötti szexuális aktussal azonosítanak. A lányok inkább szociális, nevelési okokat feltételeznek, illetve a háttérben álló múltbéli események, elszenvedett nemi erőszak, esetleges traumák kerültek lehetséges magyarázatként előtérbe (Rédai, 2011).

A tévhitek, ellentmondások, megosztó nézetek az elmélet és gyakorlat terén is megjelennek: a terminológiák, és az elmélet terén különböző vélekedésekkel, megközelítésekkel, a gyakorlatban különböző módszerekkel találkozhatunk. A háttérben meghúzódó „látens” véleményalkotás, az ellentmondásos, megosztó gondolkodás a terápiás gyakorlatban is zavart okozhat. A tudományos megközelítések, magyarázatok, a sokszínủ és sokoldalú általános ok keresési folyamatok mellett gyakran feledkezünk el az egyén szintjéről. Milyen eszközrendszer segíthet a megértésben? Hogyan tud az egyén közvetlen környezetében elfogadással találkozni? Mi segítheti a szülőt a gyermekhez való viszonyulásban? Ha a szülő a terápiás folyamat eszközét választja, mi segíthet a segítő szakmában dolgozóknak, ha esetleg családi, környezetből fakadó elutasítással, kirekesztéssel találkoznak?

Úgy vélem a szexuálpszichológia LMBTQ-terápiára (leszbikus, meleg, biszexuális, transznemü, queer), edukációra, információátadásra irányuló törekvései mentén szükséges hangsúlyozni annak fontosságát, hogy a különböző terápiás megközelítések alapjai és különbözőségei tisztázásra kerüljenek. Fontos tisztábban látnunk alapvető fogalmakat, terápiás folyamatokat annak érdekében, hogy ezen ismeretek birtokában lehetőségünk nyílhasson a kulturális, szociális, szakmai ellentmondások tisztázására, a koherens segítségnyújtásra, a nyitottságra, új alternatívák, nézőpontok képviselésére, az identitás, szükségletek, vágyak, a sokféleség megértésére. Tanulmányom során a különböző terápiás módszerek bemutatásán keresztül igyekszem az ellentmondások feloldására helyezni a hangsúlyt.

\section{A konverziós-reparatív módszerekről}

A konverziós-reparatív (helyreállító) módszer megjelenésében és fennmaradásában jelentős szerepet játszott az az alapvető társadalmi megközelítés, mely századokon át jellemzően fennállt, mely szerint a homoszexualitás deviancia. Kezdetben morálisan elítélték, majd törvényileg büntették, végül betegségnek tekintették. A 20. század közepéig ugyanis a pszichiátria általános álláspontja az volt, hogy a homoszexualitás pszichopatológiával, pszichózissal jár együtt. Thomas Szasz szerint a homoszexualitás pszichiátriai diagnózisként való nyilvántartása hasonlóan a drogfüggők kriminalizálásához a társadalmi kontroll jó példája (Kórász, 2013).

Ha ebből a megközelítésből indulunk ki, érthető tehát, hogyan kerülhetett például 1972-ben egy orvosi konferencia tematikájába a következő terápiás beavatkozás: „feltételes reflexek, elektrosokk-kezelés, drogok és sebészeti beavatkozások a homoszexualitás gyógyításának szolgálatában" (Hocquenghem, 1978, idézi Dean, 2010. 16. o.). A homoszexuálisok helyreállító terápiája korábban olyan módszerekkel is dolgozott, mely az emberi jogokat alapvetően sértette és megkérdőjelezte. 
A DSM III-ból ${ }^{1}$ kiindulva (mely tartalmazza az egodisztonikus homoszexualitás diagnózisát) Joseph Nicolosi egyfajta gyógyító szándékkal a helyreállító terápiák kialakításával, és újrakonstruálásával a homoszexualitás gyógyításának lehetőségeivel kezdett foglalkozni (Borgos, 2012). Elméletének lényege, hogy a homoszexualitás a pszichoszexuális fejlödésben bekövetkező konfliktusok, esetleges traumák hatására kialakuló jelenség, amely megváltoztatható, átalakítható (Lukács, 2013). Ezek a variánsok többek között alakulhatnak az elbizonytalanodott énkép, csökkent önbizalom, hamis szelf miatt. Az azonos nemüek iránt érzett vonzalom Nicolosi szerint az azonos nemüekkel kapcsolatos kielégítetlen érzelmi igényekből származik (Nicolosi, 2013). Munkájának megítélése a mai napig megosztja a véleményeket, nemzetközi szinten szakmai vitákat, gondolatébresztőket generált.

Dr. László Imre Nicolosi Szégyen és kötődésvesztés című könyvének ajánlásában hangsúlyozza, hogy a helyreállító terápia több, mint egy negatív szexuális magatartás megváltoztatása². A jó terápia az egész személyre fókuszál, a személyt sok szinten kívánja megváltoztatni (Nicolosi, 2013). A terápiás munka nem a homoszexuálisok kezelésére, vagy a homoszexualitás megszüntetésére vonatkozik, hanem arra, hogy folyamatosan feltárva a probléma eredetét és gyökerét eljusson a kliens arra a pontra, hogy én-idegen szexualitását stabilizálja. Ezt lehet úgyis tekinteni, mint a szégyennel sújtott személy kísérletét arra vonatkozóan, hogy nemével azonos és annak megfelelő individuáció iránti igényét kielégíthesse (Nicolosi, 2013). Nicolosi nyíltan nem vállalja, hogy a homoszexualitást betegségnek tartaná, de a homoszexualitás nem normális, nem az emberi elrendeltetés része. Megfelelő terápiás beavatkozással úgy látja, a szexuális orientáció megváltoztatható (Lukács, 2013).

Borgos Anna szerint Nicolosi elmélete speciális mintavételre épül. Olyan esetek bemutatására szükül munkássága, akik „változni szeretnének”. A terápiás cél nem az önelfogadás megerősítése, hanem a normáknak való megfelelés. Nicolosi felfogásában a családi háttér, különösen a „nárcisztikus család” fogalma meghatározó szereppel bír. A homoszexualitás szerinte tulajdonképpen nem szexuális vonzalom, sokkal inkább valami másnak a tünete, vagy hiánynak tudható be. A kezelés eredménye végül egyfajta absztinencia, a vágy globális csökkentése. Kulcsfogalmak a vallási-ideológiai normarendszer kifejezései: bűn, elfojtás, szégyen, ezáltal az is lehetséges, hogy a terápia önmagában traumatizál (Borgos, 2012).

\section{Az affirmatív megközelítésről}

Az affirmatív megközelítés nem módszert, hanem egyfajta viszonyulást jelent (Ritter, 2014). Az affirmatív szó jelentése: igenlő, megerősítő.

Az 1970-es, 1980-as évektől kezdve indult meg a melegeket támogató terápiás attitűd (Ritter, 2014). A homoszexuálisokkal folytatott terápiás munka folyamán az új családterápiás és pszichoterápiás irányzatok tükrözik leginkább az affirmatív megközelítés sajátosságait.

Figyelemmel követhetjük többek között a konstruktivista szemléletet, mely elfogadja, hogy mindenki másképp konstruál, másképp fogja fel a külvilág ingereit és másképp értelmezi azokat (Raskin, 2002). A terápiás cél ezek elfogadása, a klienssel

\footnotetext{
1 Diagnostic and Statistical Manual of Mental Disorders - magyarul Mentális rendellenességek kórmeghatározó és statisztikai kézikönyve

2 http://szolgatars.hu/szegyen-es-kotodesvesztes-konyvajanlo/
} 
történő együttműködés és azon közös felfogás kialakítása, kognícióik hogyan közelíthetnének egymáséhoz, hogyan érthetnék meg egyre inkább egymás konstrukcióit, világról alkotott nézeteit.

Az esszencialista szemlélet, mely szerint a terapeuta külső megfigyelőként van jelen a terápiás folyamatban, instruál, feladatokat ad, tereli a terápián résztvevőket (Banyard, 2013), szintén felfedezhető a megközelítésben.

A posztmodern, posztstrukturalista szociális konstruktivista szemlélet szerint konstrukcióink a minket körülvevő környezet alapján alakulhatnak ki. Ennek segítségével szocializálódunk, épülünk be a társadalmi normák rendszerébe. A terapeuta ebben a keretben maga is a rendszer részét képezi, együtt gondolkozik a klienssel, a kliens valósága, gondolatmenete, nézete szerint. Figyelembe veszi a kulturális, etnikai, nemi szexuális különbségeket. A hiedelemrendszereket együtt vizsgálják meg, konstruálják újra, amennyiben szükséges (Raskin, 2002).

A családterápiában gyakran alkalmazott narratív terápiás szemlélet szintén lehet az affirmativ megközelítés példája, hiszen elfogadja, hogy egy adott történetnek nem egy adott nézete lehet, nincs kizárólagosság, az egyén értelmez. A terapeuták segítenek, hogy a rögzült narratívákat dekonstruálják, új lehetőségeket, narratívákat tárjanak fel a klienssel együtt. Kiemeli a kulturális narratívákat, mint egyént meghatározó tényezőt, hiszen az egyén megítélése nagyban függ a családi, kulturális, vallási hovatartozásoktól. Ezek tudatosítása a kliensben segítheti a megértést és az elfogadást (McAdams, 2006).

Ritter Andrea szerint a homoszexuálisokkal folytatott legideálisabb munka a szociális konstruktivista szemlélet típus és a Queer elméletek szemléletével együttesen lenne megvalósítható (Ritter, 2014).

Az Amerikai Pszichológiai Társaság (APA) által publikált American Psychologist c. folyóiratban a Gyakorlati Útmutató a meleg, leszbikus és biszexuális kliensekkel folytatott terápiás munkához (Guidelines for Psychological Practice with Lesbian, Gay and Bisexual Clients) kiadvány több olyan tételt alkalmaz, mely újabb kutatási eredményekre alapozva iránymutatást ad az affirmatív megközelítés terápiás alkalmazására vonatkozóan:

- a társadalmi stigmatizáció, előítélet stresszforrásként történő figyelembevétele, biztonságos környezet kialakítása,

- pszichológusként fontos megérteni, hogy az LMB-identitás nem lelki, vagy mentális zavar,

- szükséges érteni, hogy az azonos nem iránt érzett vonzalom egészséges variációja az emberi szexualitásnak

- jelenlegi társadalmi, politikai hatás megértése,

- Szexuális orientáció, nemi identitás különbségeinek megértése

- fontos a kliens biztonságérzetének növelése, a stressz csökkentése, a kliens erőforrásainak fejlesztése, a trauma oldása, a szelf erősítése a coping ${ }^{3}$ érdekében,

- fontos a pszichológus tapasztalata, jártassága, képzettsége,

- a pszichológus legyen tájékozott az LMB intim kapcsolatai terén, tartsa azokat tiszteletben,

- biszexuális egyének egyedi tapasztalatainak felismerése,

- megérteni az LMB-szülők tapasztalatait, kihívásaikat,

- fontos az LMB-családok erejének, kitartásának, megküzdésének felismerése,

- a pszichológus legyen aktív és tegyen a szexuálisirányultság-alapú diszkrimináció ellen,

- a pszichológus támogassa és segítse elő a családban a melegség elfogadását,

\footnotetext{
${ }^{3}$ Pszichológiai szakkifejezés. Jelentése: megküzdési képesség.
} 
Megváltoztatni vagy elfogadni? Konverziós és affirmatív terápiák összehasonlító elemzése

- szükséges figyelembe venni, hogy a mesterséges megtermékenyítéshez, béranyasághoz való viszony stresszforrás lehet,

- társszülők családjának, szülőanya családjának hozzáállás-különbségét szükséges megérteni, elfogadni,

- a vallás, spiritualitás szerepének megértése lényeges szempont,

- az LMB-emberek közötti kor és korcsoport különbségek megértése fontos (American Psychologist, 2012)

A lista kiegészítéseként Ritter Andrea szerint a melegekkel történő terápiás munkát alapvetően határozza meg az előítélet-mentes kommunikáció használata, a homofób általános sémák tisztázása, felszínre hozása, a kliens körülményeinek körültekintő, pontos ismerete, annak feltérképezése, hogy a kliens a meleg identitás fejlődésének mely szakaszában tart (Ritter, 2014).

\section{A két terápiás megközelítés összevetéséröl}

Összességében ma már a pszichológia alapvetően azt az álláspontot képviseli, hogy a nemi irányultság megváltoztatása nem valószínü, hogy sikerrel járhat, illetve önmagában veszélyt rejt az egyént tekintve (APA Report, 2009). Láthatjuk, hogy a két terápiás megközelítés alapjaiban tér el egymástól és nehezen összeegyeztethető.

Mindkét irányzat a kliensre koncentrál, azonban míg a reparatív szemlélet a kliens egyéni - kulturális, szociális, vallási - hovatartozását figyelmen kívül hagyva a terápiás végcélt és a terápiás siker mércéjét a szexuális orientáció megváltoztatásában látja, az affirmatív megközelítés sokkal inkább a vélekedések természetessé válására, internalizálására törekszik megértve az egyén közegét. A siker mércéje inkább az elfogadás, az önbizalom növelése, a szelf erősítése, a coping kialakítása.

Míg a reparatív módszer célja, hogy a kliens a társadalmi elvárások és normák követését elsajátítsa, az affirmatív módszer hangsúlyt fektet az egyén szemléletének, útjának követésére, az elvárások, normáknak történő megfelelés, a szorongás, büntudat, szégyenérzet hátrahagyásával.

A reparatív megközelítés alapvetően implicit módon magában hordozza a homoszexualitás mint deviancia szemléletét, megerősíti a társadalmi elnyomást a homoszexuálisokkal szemben, hisz lényegében ráerősít azon vélekedésre, hogy a homoszexualitás nem normális, a társadalom rendjébe, müködésébe nem beépíthető, javítani szükséges. A módszer hátterében érezhető a vallási és társadalmi hovatartozás kérdése. Laird szerint például a melegek nem azért küzdenek saját identitásuk elfogadásával, mert önmagában problémának tekintik identitásuk elfogadását, hanem azért, mert az őket körülvevő kultúra nem fogadja el azt (Laird, 1998). Az affirmatív megközelítés ezzel szemben nem képvisel semmilyen nézetet, nem kötődik egyik vallási felekezethez, politikai szemlélethez sem, kizárólag a kliens megértésére fókuszál.

A reparatív megközelítés szerint annak szükséges segíteni, aki változásra érett, aki a változás útjára kíván lépni. A kliens szeretné megérteni a saját traumáját és okságát, miért lett homoszexuális. Lényegében az, hogy okokat keresünk a homoszexualitás mögött, azt sugallja, hogy ez egy olyan elváltozás, melyet ha kézzelfoghatóvá, mérhetővé és visszafejthetővé teszünk, a megoldására is szert teszünk egyben. Ezáltal legitimáljuk, hogy a szexuális orientációk nem egyenrangúak, köztük különbség van, hiszen míg a heteroszexualitás eredetét nem próbáljuk apró részletességgel feltárni, a homoszexualitás okságának feltárására mügonddal ügyelünk. Abban az esetben, ha a kliens felé alapvető nyitottsággal és elfogadással közelítünk, ahogy az affirmatív szemlélet teszi, ilyen kitételek feleslegesnek tűnnek. Az affirmatív megközelítés célja sokkal inkább az egyenrangúság érzésének erősítése, a másság, a diszkrimináció érzésének csökkentése. 


\section{Összefoglalás}

A kategóriák, az előítéletek, a diszkrimináció, a sztereotípiák nem segítik azt a célt, mely önmagában kulcsfontosságú: a másik megértését. Összességében úgy vélem, a tudományok, és minden ember alapvető feladata többek között az, hogy minél inkább útmutatással éljen. Útmutatással éljünk azok felé, akik megosztóan vélekednek, akik hiányos ismeretekkel rendelkeznek az új irányzatok, a tudományos kutatások, a kutatások eredményei terén. Azok felé, akik szakmai állásfoglalásuk szerint inkább helyreállítanának, mint megértő módon közelednének. És útmutatással élhetünk kicsit önmagunk és saját önismereti folyamatunk felé is annak érdekében, hogy segítségnyújtásunk minél inkább hatékony lehessen, odafordulásunk a másik egyénről szólhasson, nem önmagunkról, nem a társadalmi, kulturális, szociális, vallási, politikai elvárásokról, vagy hovatartozásról.

A megértés folyamata segít tudomásul venni, hogy olyan adottságról van szó, mely nem megszüntethető, nem befolyásolható, nem megelőzhető, nem elkerülhető. A hangsúly ezáltal sokkal inkább az elfogadásra, az együttélés megkönnyítésére tehető. A kérdés nem a „miért?” lesz, hanem a „hogyan?".

A megértés folyamata helyett tartott oknyomozás a homoszexualitás jelenségét tekintve káros folyamat. A jövő helyett figyelmünket a múlt felé irányítja. Hiába létezne egyértelmű, kimutatható, bizonyítható ok, a felismerés a homoszexuális érintettséget, ennek felvállalásának, elfogadásának folyamatát nem könnyítené meg. A fennálló általános előítéletekkel, sztereotípiákkal szemben a védelmet nyújtó, segítő szükebb környezet szerepe (család, barátok, segítő szakemberek) felértékelődik.

„Ahogy a meleg ember nem választotta nemi irányultságát, úgy a szülő sem választotta, hogy a gyereke meleg legyen. De ha már ez lett a sorsa, akkor jobban jár, ha szembenéz vele, mintha megpróbál elmenekülni elöle” (Fischer, 2010. 75. o.). „A jó családi életet, a szülő-gyerek kapcsolat intimitását nem a gyerek melegsége veszélyezteti, hanem az ellene folytatott kilátástalan küzdelem" (Fischer, 2010. 76. o.). Terápiás folyamataink és munkánk során a tanulmányban összegyűjtött sokszínű szempontok, vizsgálatok és nézetek segítséget nyújthatnak annak érdekében, hogy mi magunk is megértsük és nyitottak legyünk egymás sokszínüségére is.

\section{Felhasznált irodalom}

Banyard, P., Dillon, G., Norman, C. \& Winder, B. (2013): Essential psychology. India: Replika Press.

Bieber, I., et al. (1962): Homosexuality. A Psychoanalytic Study of Male Homosexuals. Basic Books, USA.

Borgos Anna (2013): Joseph J. Nicolosi: Szégyen és kötődésvesztés. A helyreállító terápia gyakorlata (recenzió). Pszichoterápia, 21. 6. sz. 414-417.

Dean, T. \& Lane, C. (2010): Homoszexualitás és pszichoanalízis - Bevezetés. Thalassa, 21. 4. sz., 5-38.

Dombos Tamás, Takács Judit, P. Tóth Tamás és Mocsonaki László (2011): Az LMBT emberek magyarországi helyzetének rövid áttekintése. In: Takács Judit (szerk.), Homofóbia Magyarországon. L'Harmattan Kiadó, Budapest, 38-41.

Fischer Eszter (2010): Meleg a gyerekem?! Saxum Kiadó Kft. Budapest.

Guidelines for Psychological Practice with Lesbian, Gay and Bisexual Clients (2012). American Psychologist, 67. 1. sz., 10-42.

Hill, A., K., Dawood, K. \& Puts, D. A. (2012): Biological Foundations of Sexual Orientation. In Patterson, Ch. J. \& D'Augelli A. R. (szerk.): Handbook of Psychology and Sexual Orientation. Oxford University Press, New York. 
Dean, T. és Lane, C. (2010): Homoszexualitás és pszichoanalízis - Bevezetés. Thalassa, 21. 4. sz., 5-38.

Kinnunen, L., H., Moltz, H., Metz, J. \& Cooper, M. (2004): Differential brain activation in exclusively homosexual and heterosexual men produced by the selective serotonin reuptake inhibitor, fluoxetine. Brain Research, 1024. 1-2. sz., 251-254.

Kórász Krisztián (2013): A homoszexualitás demedikalizációja - a bűntől, büntetéstől az egyenlőség felé. Lege Artis Medicinae, 23. 5-6. sz., 316-320.

Laird, J. (1998): Theorizing culture. In: McGoldrick M. (szerk.): Re-visioning family therapy: Race, culture, and gender in clinical practice. Guilford Press, New York.

Lukács Dénes (2013): Kell-e gyógyítani a homoszexualitást? Magyar Családterápiás Egyesület: Vita a homoszexualitásról. publikálatlan előadás

McAdams, D. P. (2006): The role of narrative in personality psychology today. Narrative Inquiry, 16. 1. sz., 11-18.

Michael, R. T., Gagnon, J. H., Laumann, E. O. \& Kolata, G. (1994): Sex in America: A Definitive Survey. Little, Brown and Co, Boston.

Nicolosi, J. J. (2013): Szégyen és kötődésvesztés. A helyreállító terápia gyakorlata. Harmat, Budapest.

Raskin, J. D. (2002): Constructivism in psychology: Personal construct psychology, radical constructivism, and social constructionism. In: Raskin, J. D. \& Bridges, S. K. (szerk.), Studies in meaning: Exploring constructivist psychology. Pace University Press, New York, $1-25$.

Report of the American Psychological Association Task Force on Appropriate Therapeutic Responses to Sexual Orientation (2009): www.apa.org/pi/lgbc/publications/

Rédai Dorottya (2011): „...Én az olyanokat értem meg, akik nem tehetnek róla” Középiskolás heteroszexuális diákok diskurzusai a melegség kialakulásáról. In: Takács Judit (szerk.), Homofóbia Magyarországon. L'Harmattan Kiadó. Budapest, 149-150.

Ritter Andrea (2014): Melegek. Ismeretlen ismerösök a 21. században. Corvina, Budapest.

Takács, István Károly (2011): A homofóbia nyomai a magyar közoktatásban - Egy szegedi vizsgálat tanulságai. In: Takács Judit (szerk.): Homofóbia Magyarországon. L'Harmattan Kiadó. Budapest, 154-155.

Takács Judit (2011): Homofóbia Magyarországon és Európában. In: Takács, Judit (szerk.): Homofóbia Magyarországon. L'Harmattan Kiadó. Budapest, 16-17.

Whitehead, N. \& Whitehead, B. (1999): My Genes Made Me Do It. Huntington House Publishers, Lafayette, LA. 